\title{
EVALUATION OF TOPICAL 30\% POTASSIUM HYDROXIDE VERSUS 30\% TRICHLOROACETIC ACID IN THE TREATMENT OF PLANE WARTS
}

\author{
By
}

\section{Attia Attia Ali Attia Alawady, Hamed Mohamed Abdo and Mohammed Abd El-Mawgoud Amer}

Department of Dermatology, Venereology and Andrology, Faculty of Medicine, Al-Azhar University

\author{
Corresponding Author: Attia Attia Ali Attia Alawady, \\ Phone: +201025435865, E-mail: attiaalawady282@gmail.com
}

\begin{abstract}
Background: Warts are benign proliferation of skin and mucosa that result from infection with human papilloma virus (HPV) which are double stranded deoxyribonucleic acid (DNA) viruses that replicate inside the nucleus. Infection with HPV may be clinical, subclinical, or latent.

Objective: To compare the efficacy and safety of potassium hydroxide $30 \%(\mathrm{KOH})$ versus trichloroacetic acid $30 \%$ (TCA) in treatment of plane warts.

Patients and methods: Our study was carried out on 60 patients complaining of plane warts divided into A and B from November 2019 to March 2020, Group A: thirty patients treated by potassium hydroxide (KOH 30\%) weekly and Group B: thirty patients treated by trichloroacetic acid (TCA 30\%) weekly for maximum period of 12 weeks, with pointed end of a wooden applicator to the center of all the lesions until a white frost appeared. Patients were selected from out-patient clinic of Dermatology, Venereology and Andrology Department of Al-Azhar University Hospitals.

Results: The present study showed complete cure rates of 7 patients $(23.3 \%)$ in group A and 7 patients $(23.3 \%)$ in group B. Partial cure rates occurred in 15 patients $(50 \%)$ in group A and 16 patients $(53,3 \%)$ in group B after 12 weeks of treatment. No response occurred in 8 patients (27.6\%) in group A and 7 patients $(23.3 \%)$ in group B. All nonresponsive patients had lesions in sites other than face except for 2 patients, one in each group had facial lesions.

Conclusion: Based on our findings, both potassium hydroxide (KOH 30\%) and trichloroacetic acid (TCA $30 \%)$ are equally effective in treatment of plane warts without statistically significant difference at end of treatment period and follow up, but TCA (30\%) was safer than $\mathrm{KOH} \mathrm{(30 \% ).}$
\end{abstract}

Keywords: $30 \%$ Potassium Hydroxide, 30\% Trichloroacetic Acid, Plane Warts.

\section{INTRODUCTION}

Warts are common epidermal growths caused by various strains of human papillomavirus (HPV) affecting all age groups. They have an unsightly appearance and are mostly asymptomatic but sometimes may be painful. The virus initially targets the basal cells and undergoes a latent phase of slow replication. As the epidermis grows superficially, the virus induces hyperplasia and hyperkeratosis (Aldahan et al., 2016). 
There are five major HPV genera: Alpha papilloma virus, Beta papilloma virus, Gamma papilloma virus, $\mathrm{Mu}$ papilloma virus and $\mathrm{Nu}$ papilloma virus. HPVs infect epithelial cells in genital mucosa (alpha papilloma viruses only), while oral mucosa and skin by all the five genera (Bzhalava et al., 2013).

Cutaneous warts are one of the most common dermatoses in children, the prevalence of cutaneous warts among school children in Egypt is variable from $2.4 \%$ to $33 \%$, with an equal frequency in both sexes (Kasim et al., 2013), and the prevalence of warts for both children and adults range from 5 to $20 \%$ (El Mohamady et al., 2014).

Flat warts are associated with HPV types 2, 3, 10, 27, 28, 38, 41 and 49 . These are found in the peripheral areas of the face, back of the hands and pretibial areas in children and youths. Linear grouping is typical following scratch lines (isomorphism or koebnerization) (Cardoso and Calonje, 2011).

Treatment of warts represents a continuing challenge for dermatologists as many of the available therapeutic modalities are associated with unsatisfactory results and high recurrence rates (Saini et al., 2016).

Potassium hydroxide $(\mathrm{KOH})$ is a strong base used in the diagnosis of fungal infections, treatment of male genital warts, and treatment of molluscum contagiosum in children (Camargo et al., 2014).

$\mathrm{KOH}(5 \%$ and $10 \%)$ solution acts by its keratolytic effects that lead to the destruction of virus-infected cells causing resolution of warts. It is less irritating, less painful, less scar forming, and can be safely used in children too. Rarely, side effects such as itching, erythema, and dyspigmentation may be seen (AlHamamy et al., 2012).

Trichloroacetic Acid (TCA) is a topical destructive agent and causes hydrolysis of cellular proteins leading to cell death. It is effective in treating common, cervical, genital, and anal warts in the concentrations of $70-80 \%$ and has response rates comparable to cryotherapy (Pezeshkpoor et al., 2012).

The aim of this work was to compare the efficacy and safety of potassium hydroxide $30 \% \quad(\mathrm{KOH}) \quad$ versus trichloroacetic acid 30\% (TCA) in treatment of Plane warts.

\section{PATIENTS AND METHODS}

This study was carried out on a total of 60 patients with plane warts from November 2019 to March 2020. The patients were diagnosed by typical clinical findings. The patients were able to read and give consents. Patients under any other treatment modalities, with present or past history of herpes, with present or past history of keloid, pregnant and lactating females were excluded. Patients were selected from out-patient clinic of Dermatology, Venereology and Andrology Department of Al-Azhar University Hospitals.

All patients were subjected to complete medical history, dermatological examination and documented digital photography. 
EVALUATION OF TOPICAL 30\% POTASSIUM HYDROXIDE VERSUS... 2055

The patients were divided into two equal groups:

Group A: $\mathrm{KOH} 30 \%$ group was subjected to weekly application of $(30 \%) \mathrm{KOH}$ solution by wooden stick after applying a thin film of vaseline petrolatum around the lesions till the complete clearance or a maximum period of 12 weeks.

Group B: TCA $30 \%$ was subjected to weekly application of (30\%) TCA solution by wooden stick after applying a thin film of vaseline petrolatum around the lesions till the complete clearance or a maximum period of 12 weeks.

\section{Response to treatment:}

i. Complete response: total clearance of warts.

ii. Partial resolution: noticeable improvement but not full clearance.

iii. No response: absolutely no improvement.
Follow-up of patients was done every 2 weeks for 2 months to detect any recurrence. The side effects of treatment were recorded such as erythema, burning sensation,

hypopigmentation, hyperpigmentation and Scar Formaticn.

\section{Statistical analysis:}

Results of the present study were statistically analyzed using SPSS 25 (IBM, USA). Data were represented as median (interquartile range) or number and percentage. Numerical data were compared using Mann-Whitney U test, while categorical data were compared using Fisher's exact test or Chi-square test as appropriate. ROC curve was used to evaluate the performance of different tests differentiate between certain groups. $\mathrm{P}$ value $<0.05$ was significant.

\section{RESULTS}

Regarding demographic data, there was no statistically significant difference between both groups regarding age, sex, duration of lesions and previous treatments.

The findings of our study regarding male to female ratio $(56: 44 \%)$, median age group affected (11-13.5). the most of plane warts lesions were facial in 46 patients $(76.6 \%), 6$ patients $(10 \%)$ had lesions in the neck, 7 patients $(11.65 \%)$ had lesions in the upper limb and one patient $(1.7 \%)$ had lesions in the trunk (Table 1).

Table (1): Comparison between studied groups as regard demographic data

\begin{tabular}{|c|c|c|c|c|c|c|c|c|}
\hline \multicolumn{2}{|c|}{$\begin{array}{ll}\text { Demographic data } & \text { Groups } \\
\end{array}$} & \multirow{2}{*}{\multicolumn{2}{|c|}{$\begin{array}{c}\begin{array}{c}\mathbf{K O H} \\
(\mathbf{N}=\mathbf{3 0})\end{array} \\
14.3 \pm 7.3 \\
\end{array}$}} & \multirow{2}{*}{\multicolumn{2}{|c|}{$\begin{array}{c}\text { TCA } \\
(\mathbf{N}=\mathbf{3 0})\end{array}$}} & \multicolumn{2}{|c|}{ Stat. test } & $\begin{array}{c}\text { P- } \\
\text { value }\end{array}$ \\
\hline \multirow{2}{*}{ Age (years) } & \multirow{2}{*}{\begin{tabular}{|c|} 
Mean \pm SD \\
Median
\end{tabular}} & & & & & \multirow{2}{*}{ MW } & \multirow{2}{*}{379} & \multirow{2}{*}{0.293} \\
\hline & & & & & 3.5 & & & \\
\hline \multirow{2}{*}{ Sex } & Male & 15 & $50 \%$ & 19 & $63.3 \%$ & \multirow{2}{*}{$X^{2}$} & \multirow{2}{*}{1.08} & \multirow{2}{*}{0.297} \\
\hline & Female & 15 & $50 \%$ & 11 & $36.7 \%$ & & & \\
\hline \multirow{2}{*}{$\begin{array}{l}\text { Duration } \\
\text { (month) }\end{array}$} & Mean \pm SD & \multicolumn{2}{|c|}{$24.2 \pm 17.9$} & \multicolumn{2}{|c|}{$19.7 \pm 13.9$} & \multirow{2}{*}{ MW } & \multirow{2}{*}{398.5} & \multirow{2}{*}{0.443} \\
\hline & Median & \multicolumn{2}{|c|}{23} & \multicolumn{2}{|c|}{16} & & & \\
\hline \multirow{2}{*}{ Previous TTT } & No & 6 & $20 \%$ & 1 & $3.3 \%$ & \multirow{2}{*}{$\mathbf{X}^{2}$} & \multirow{2}{*}{4.04} & \multirow{2}{*}{0.044} \\
\hline & Yes & 24 & $80 \%$ & 29 & $96.7 \%$ & & & \\
\hline
\end{tabular}


Regarding response to treatments, both treatments were effective with no statistically significant difference between both studied groups as regard response. This study showed complete cure rates in 7 patients $(23.3 \%)$ in Group A, 7 patients $(23.3 \%)$ in Group B and partial cure rates in 15 patients $(50 \%)$ in group $A, 16$ patients $(53,3 \%)$ in Group B after 12 weeks of treatment.

No response occurred in 8 patients $(27.6 \%)$ in Group $A$ and 7 patients $(23.3 \%)$ in Group B, all nonresponsive patients had lesions in sites other than face except 2 patients one in each group had facial lesions (Table 2).

Table (2): Comparison between studied groups as regard response

\begin{tabular}{|c|c|c|c|c|c|c|c|c|}
\hline \multicolumn{2}{|c|}{ Response Groups } & \multicolumn{2}{|c|}{$\begin{array}{c}\text { KOH } \\
(\mathbf{N}=30)\end{array}$} & \multicolumn{2}{|c|}{$\begin{array}{c}\text { TCA } \\
(\mathbf{N}=\mathbf{3 0})\end{array}$} & \multicolumn{2}{|c|}{ Stat. test } & $\begin{array}{c}\mathbf{P}- \\
\text { value }\end{array}$ \\
\hline \multirow{3}{*}{$\begin{array}{c}1^{\text {st }} \\
\text { month }\end{array}$} & No response & 13 & $43.3 \%$ & 9 & $30 \%$ & \multirow{3}{*}{$\mathrm{X}^{2}$} & \multirow{3}{*}{1.3} & \multirow{3}{*}{0.517} \\
\hline & Partial response & 16 & $53.3 \%$ & 19 & $63.3 \%$ & & & \\
\hline & Complete response & 1 & $3.3 \%$ & 2 & $6.7 \%$ & & & \\
\hline \multirow{3}{*}{$\begin{array}{c}2^{\text {nd }} \\
\text { month }\end{array}$} & No response & 8 & $26.7 \%$ & 8 & $26.7 \%$ & & & \multirow{3}{*}{1.0} \\
\hline & Partial response & 17 & $56.7 \%$ & 17 & $56.7 \%$ & & & \\
\hline & Complete response & 5 & $16.7 \%$ & 5 & $16.7 \%$ & & & \\
\hline \multirow{3}{*}{$\begin{array}{c}3^{\text {rd }} \\
\text { month }\end{array}$} & No response & 8 & $26.7 \%$ & 7 & $23.3 \%$ & \multirow{3}{*}{$X^{2}$} & \multirow{3}{*}{0.1} & \multirow{3}{*}{0.952} \\
\hline & Partial response & 15 & $50 \%$ & 16 & $53.3 \%$ & & & \\
\hline & Complete response & 7 & $23.3 \%$ & 7 & $23.3 \%$ & & & \\
\hline
\end{tabular}

Regarding to relation between response and (sex \& duration) in $\mathrm{KOH}$ group, there was no statistically significant relation. There was a statistically significant relation complete response was more evident with younger age $(10.1 \pm 3.8$ years) as compared to partial response $(13.5 \pm 7.5$ years $)$ and no partial response
(19.3 \pm 6.9 years).Regarding to relation between response and site of lesion in $\mathrm{KOH}$ group, there was a highly statistically significant relation as complete and partial responses were more evident in face (100\%) as compared to no response $(12.5 \%$ in face, $50 \%$ in neck and $37.5 \%$ in the upper limb) (Table 3).

Table (3): Relations between response and other studied parameters in $\mathrm{KOH}$ group

\begin{tabular}{|c|c|c|c|c|c|c|c|c|c|c|}
\hline \multicolumn{2}{|c|}{$\begin{array}{ll}\text { KOH group } & \text { Response }\end{array}$} & \multicolumn{2}{|c|}{$\begin{array}{c}\text { No } \\
(\mathbf{N}=8)\end{array}$} & \multicolumn{2}{|c|}{$\begin{array}{l}\text { Partial } \\
(\mathrm{N}=15)\end{array}$} & \multicolumn{2}{|c|}{$\begin{array}{c}\text { Complete } \\
(\mathrm{N}=7)\end{array}$} & \multicolumn{2}{|c|}{ Stat. test } & \multirow{3}{*}{\begin{tabular}{|c|} 
P-value \\
0.097
\end{tabular}} \\
\hline \multirow{2}{*}{ Sex } & Male & 3 & $37.5 \%$ & 6 & $40 \%$ & 6 & $85.7 \%$ & \multirow{2}{*}{$X^{2}$} & \multirow{2}{*}{4.67} & \\
\hline & Female & 5 & $62.5 \%$ & 9 & $60 \%$ & 1 & $14.3 \%$ & & & \\
\hline \multirow{3}{*}{ Site } & Face & 1 & $12.5 \%$ & 15 & $100 \%$ & 7 & $100 \%$ & \multirow{3}{*}{$\mathbf{X}^{2}$} & \multirow{3}{*}{25.1} & \multirow{3}{*}{$<0.001$} \\
\hline & Neck & 4 & $50 \%$ & 0 & $0 \%$ & 0 & $0 \%$ & & & \\
\hline & Upper limb & 3 & $37.5 \%$ & 0 & $0 \%$ & 0 & $0 \%$ & & & \\
\hline Age (years) & Mean \pm SD & \multicolumn{2}{|c|}{$19.3 \pm 6.9$} & \multicolumn{2}{|c|}{$13.5 \pm 7.6$} & \multicolumn{2}{|c|}{$10.1 \pm 3.8$} & $\mathbf{F}$ & 3.6 & 0.041 \\
\hline $\begin{array}{l}\text { Duration } \\
\text { (month) }\end{array}$ & Mean \pm SD & \multicolumn{2}{|c|}{$23.3 \pm 9.8$} & \multicolumn{2}{|c|}{$26.7 \pm 22.9$} & \multicolumn{2}{|c|}{$19.8 \pm 13.3$} & $\mathrm{~F}$ & 0.34 & 0.710 \\
\hline
\end{tabular}

Regarding to relation between response and (sex, age \& duration) in TCA group, there was no statistically significant relation (Table 4).
There was a highly statistically significant relation as complete and partial responses were more evident in face $(100 \%)$ as compared to no response $(0 \%$ 
EVALUATION OF TOPICAL 30\% POTASSIUM HYDROXIDE VERSUS... ${ }^{2057}$

in face, $28.6 \%$ in neck, $57.1 \%$ in the upper $\quad$ limb\& $14.3 \%$ in trunk) (Table 4).

Table (4): Relations between response and other studied parameters in TCA group

\begin{tabular}{|c|c|c|c|c|c|c|c|c|c|c|}
\hline \multirow{2}{*}{\multicolumn{2}{|c|}{$\mathrm{T}_{\text {TCA group }}$ Response }} & \multicolumn{6}{|c|}{ Response } & \multirow{2}{*}{\multicolumn{2}{|c|}{ Stat. test }} & \multirow{4}{*}{\begin{tabular}{|c} 
P-value \\
0.231
\end{tabular}} \\
\hline & & \multicolumn{2}{|c|}{$\begin{array}{c}\text { No } \\
(\mathbf{N}=7)\end{array}$} & \multicolumn{2}{|c|}{$\begin{array}{c}\text { Partial } \\
(\mathrm{N}=16)\end{array}$} & \multicolumn{2}{|c|}{$\begin{array}{c}\text { Complete } \\
(\mathbf{N}=7)\end{array}$} & & & \\
\hline \multirow{2}{*}{ Sex } & Male & 5 & $71.4 \%$ & 8 & $50 \%$ & 6 & $85.7 \%$ & \multirow{2}{*}{$X^{2}$} & \multirow{2}{*}{2.9} & \\
\hline & Female & 2 & $28.6 \%$ & 8 & $50 \%$ & 1 & $14.3 \%$ & & & \\
\hline \multirow{4}{*}{ Site } & Face & 0 & $0 \%$ & 16 & $100 \%$ & 7 & $100 \%$ & \multirow{4}{*}{$X^{2}$} & \multirow{4}{*}{30} & \multirow{4}{*}{$<0.001$} \\
\hline & Neck & 2 & $28.6 \%$ & 0 & $0 \%$ & 0 & $0 \%$ & & & \\
\hline & Upper limb & 4 & $57.1 \%$ & 0 & $0 \%$ & 0 & $0 \%$ & & & \\
\hline & Trunk & 1 & $14.3 \%$ & 0 & $0 \%$ & 0 & $0 \%$ & & & \\
\hline Age (years) & Mean \pm SD & \multicolumn{2}{|c|}{$19.1 \pm 8.6$} & \multicolumn{2}{|c|}{$16.3 \pm 6.9$} & \multicolumn{2}{|c|}{$10.4 \pm 4.1$} & $\mathrm{~F}$ & 2.9 & 0.068 \\
\hline $\begin{array}{l}\text { Duration } \\
\text { (month) }\end{array}$ & Mean \pm SD & \multicolumn{2}{|c|}{$14.7 \pm 11.5$} & \multicolumn{2}{|c|}{$22.8 \pm 15.5$} & \multicolumn{2}{|c|}{$17.7 \pm 11.3$} & $\mathrm{~F}$ & 0.92 & 0.409 \\
\hline
\end{tabular}

There was no statistically significance between both studied groups as regard erythema, burning sensation and hyperpigmentation, but there was a statistically significant difference between both studied groups as regard hypopigmentation, in $\mathrm{KOH}$ group more than TCA group (Table 5).

Table (5): comparison between studied groups as regard side effects

\begin{tabular}{|c|c|c|c|c|c|c|c|c|}
\hline \multicolumn{2}{|c|}{$\begin{array}{ll}\text { Side effects } & \text { Groups } \\
\end{array}$} & \multicolumn{2}{|c|}{$\begin{array}{c}\text { KOH } \\
(\mathbf{N}=\mathbf{3 0})\end{array}$} & \multicolumn{2}{|c|}{$\begin{array}{c}\text { TCA } \\
(\mathbf{N}=\mathbf{3 0})\end{array}$} & \multicolumn{2}{|c|}{ Stat. test } & \multirow{3}{*}{\begin{tabular}{|c|} 
P-value \\
--- \\
\end{tabular}} \\
\hline \multirow{2}{*}{ Erythema } & No & $\mathbf{0}$ & $0 \%$ & $\mathbf{0}$ & $0 \%$ & \multirow[b]{2}{*}{---} & \multirow{2}{*}{---} & \\
\hline & Yes & 30 & $100 \%$ & 30 & $100 \%$ & & & \\
\hline \multirow{2}{*}{ Burning sensation } & No & 0 & $0 \%$ & 0 & $0 \%$ & \multirow{2}{*}{---- } & \multirow{2}{*}{---} & \multirow{2}{*}{---} \\
\hline & Yes & 30 & $100 \%$ & 30 & $100 \%$ & & & \\
\hline \multirow{2}{*}{ Hypopigmentation } & No & 11 & $36.7 \%$ & 19 & $63.3 \%$ & \multirow{2}{*}{$\mathbf{X}^{2}$} & \multirow{2}{*}{4.3} & \multirow{2}{*}{0.039} \\
\hline & Yes & 19 & $63.3 \%$ & 11 & $36.7 \%$ & & & \\
\hline \multirow{2}{*}{ hyperpigmentation } & No & 28 & 93.3\% & 30 & $100 \%$ & \multirow{2}{*}{$\mathbf{X}^{2}$} & \multirow{2}{*}{2.06} & \multirow{2}{*}{0.49} \\
\hline & Yes & 2 & $6.7 \%$ & 0 & $0 \%$ & & & \\
\hline
\end{tabular}






Before

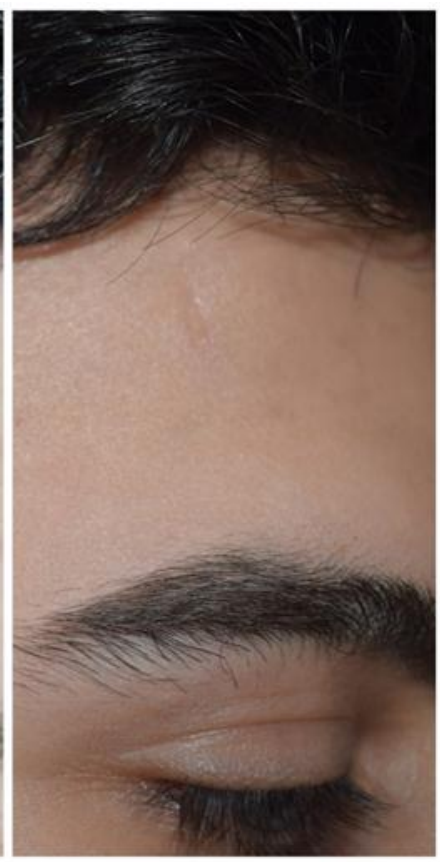

After

Figure (1): A 20 years old male with facial plane warts before and after treatment showing complete clearance after 4 weeks of $\mathrm{KOH} 30 \%$ application.

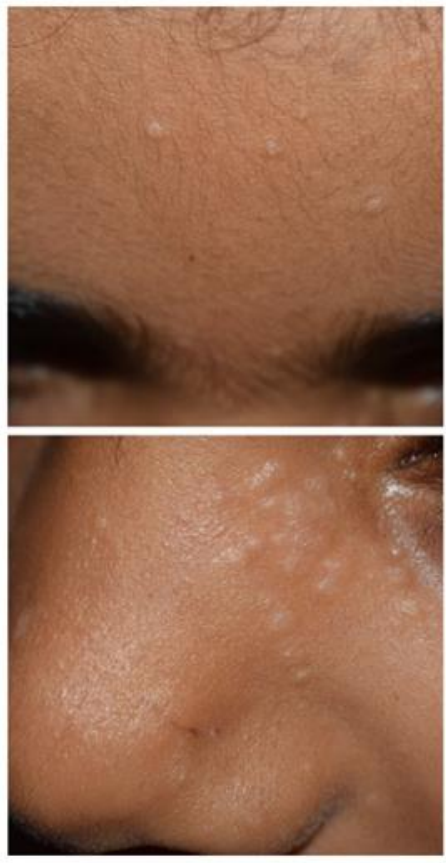

Before

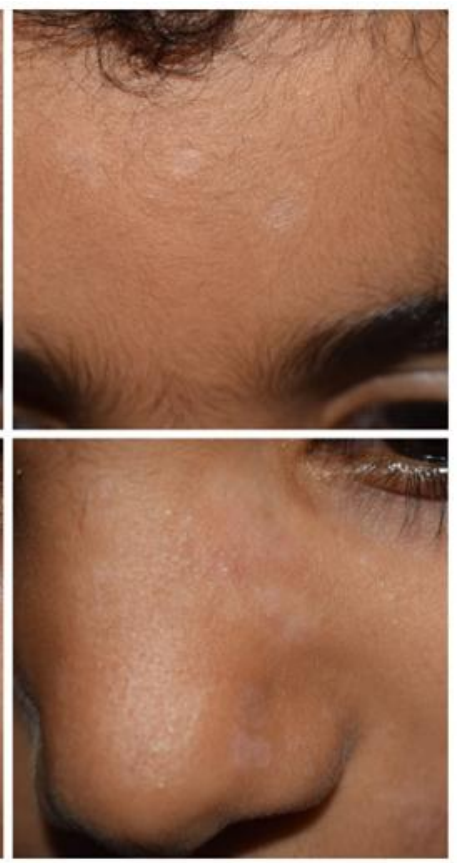

After

Figure (2): A 9 years old male with facial plane warts before and after treatment showing complete clearance with slight hypopigmentation after 4 weeks of TCA 30\% application. 


\section{DISCUSSION}

This study was carried out on 60 patients complaining of plane warts, 30 patients (Group A) were treated by $\mathrm{KOH}$ $30 \%$ weekly and 30 patients (Group B) were treated by TCA $30 \%$ weekly. All patients completed the study. Both modalities were effective and considered promising options in treatment of plane warts without statistically significant difference between both of them.

In this study, there was no significant difference between both groups regarding age, sex, duration and sites of lesions.

The present study showed complete cure in 7 patients $(23.3 \%)$ in both groups (A and B) with partial cure in 15 patients $(50 \%)$ in Group $A$, and 16 patients $(53.3 \%)$ in Group B after 12 weeks of treatment. No response occurred in 8 patients $(27.6 \%)$ in Group A, and 7 patients $(23.3 \%)$ in Group B. All nonresponsive patients had lesions in sites other than face except 2 patients, one in each group, had facial lesions. Both modalities did not give any response in neck, upper limb and trunk lesions. Recurrence occurred in 10 patients of Group A and 12 patients of Group B.

The reported side effects were mild burning sensation, transient erythema, hypopigmentation, hyperpigmentation. Side effects were equal in both groups except hypopigmentation which occurred in Group A more than Group B.

In literature, there are no studies about using $\mathrm{KOH}(30 \%)$ in treatment of plane warts.

In agreement with this study, Yaghoobi et al. (2019) compared the effect of (10\%) $\mathrm{KOH}$ and $(50 \%)$ TCA solutions in patients with plane warts and found that both treatments were effective, and there was no significant difference between both groups in clinical response and side effects. They had more complete cure rates which may be due to the difference in quality of solutions, site of lesions and skin type of patients. In disagreement with this study, they found recurrence only in two patients in TCA group, that was may be due to the difference in number, duration of lesions or the quality of solutions.

Jayaprasad et al. (2016) compared effect of $(10 \%) \mathrm{KOH}$ and $(30 \%)$ TCA solutions in patients with plane warts and found that both treatments were effective, and there was no significant difference between both groups in clinical response which was in agreement with this study and had more complete cure rates which may be due to the difference in quality of solutions, site of lesions and the skin type of patients. They also found that hypopigmentation occurred in group treated with TCA $(30 \%)$ more than those treated with $\mathrm{KOH}(10 \%)$ which was in disagreement of this study which may be due to the high concentration of $\mathrm{KOH}$ used in this study. There was no recurrence rate which may be due to the difference in number of lesions or the good immune response of patients.

In contrast to this study, Al-Hamdi and Al-Rahmani, (2012) compared the effect of $(5 \%)$ and $(10 \%) \mathrm{KOH}$ on plane warts with once daily night application for 4 weeks and had more complete cure rates which may be due to the difference in treatment method which was once daily and all warts in were located on the face. 
In agreement with this study, Rezk et al. (2017) compared the effect of daily application of $\mathrm{KOH}(10 \%)$ and $(15 \%)$ on plane warts for 4 weeks and found that $\mathrm{KOH}$ is effective in both concentrations, but had more complete cure rates which may be due to the difference in treatment method which was once weekly in this study. In spite of the lower concentrations of $\mathrm{KOH}$ used, the side effects were in agreement with the present study which may be due to the daily application of $\mathrm{KOH}$.

Pezeshkpoor et al. (2012) compared the effect of $80 \%$ TCA and 35\% TCA on patients with plane warts once per week until complete clearance of the lesions or for a maximum duration of 6 weeks, and found that complete cure rates occurred in group treated by (80) TCA. However, this study had more cure rates which may be due to the difference in treatment period which was 12 in this study. In spite of the high concentration of TCA used, the side effects were in agreement with the present study which may be due to the difference in treatment period which was 6 weeks.

Both modalities were promising in treatment of plane warts, but immunotherapy was used to increase the efficacy and reduce the recurrence rate.

\section{CONCLUSION}

Both potassium hydroxide ( $\mathrm{KOH} 30 \%$ ) and trichloroacetic acid (TCA30\%) were equally effective in treatment of plane warts without statistically significant difference at end of treatment period and follow up, but TCA $30 \%$ was safer than KOH $30 \%$.

Conflicts of interest: no conflicts of interest were encountered.

\section{REFERENCES}

1. Aldahan AS, Mlacker S, Shah VV, Kamath P, Alsaidan M, Samarkandy S and Nouri $K$ (2016): Efficacy of intralesional immunotherapy for the treatment of warts. A review of the literature. Dermatol Ther., 29 (3):197-207.

2. Al-Hamamy HR, Salman HA and Abdulsattar NA (2012): Treatment of plane warts with a low-dose oral isotretinoin. ISRN Dermatol., 1-3.

3. Al-Hamdi KI and Al-Rahmani MA (2012): Evaluation of topical potassium hydroxide solution for treatment of plane warts. Indian Journal of Dermatology; 57(1):38-41.

4. Bzhalava, D.; Guan, P.; Franceschi, S.; Dillner, J. and Clifford, G., (2013): A systematic review of the prevalence of mucosal and cutaneous human papillomavirus types. Virology 445:224-31.

5. Camargo CL, Belda Junior W, Fagundes LJ and Romiti R (2014): A prospective, open, comparative study of $5 \%$ potassium hydroxide solution versus cryotherapy in the treatment of genital warts in men. A Bras Dermatol., 89(2):236-240.

6. Cardoso JC and Calonje E (2011): Cuteneous manifestations of human of human papillomaviruses. Acta Dermato venerol Alp Pannonica Adriat., 20 (3): 145-154.

7. El-Mohamady Adel-S, Mearag I, ElKhalawany M, Elshahed A, Shokeir $\mathrm{H}$ and Mahmoud A (2014): Pulsed dye laser versus Nd: YAG laser in the treatment of plantar warts: a comparative study. Lasers Med Sci., 29(3): 1111-1116.

8. Jayaprasad S, Subramaniyan $R$ and Devgan S (2016): Comparative Evaluation of Topical 10\% Potassium Hydroxide and 30\% Trichloroacetic Acid in the Treatment of Plane Warts. Indian J Dermatol., 61(6): 634639.

9. Kasim, K.; Amer, S.; Mosaad, M.; AbdelWahed., A and Allam, H., (2013): Some Epidemiologic Aspects of Common Warts in Rural Primary School Children. Int Sch Res Not., 1300: 1-6. 
EVALUATION OF TOPICAL 30\% POTASSIUM HYDROXIDE VERSUS... 2061

10. Pezeshkpoor F, Banihashemi M, Yazdanpanah MJ, Yousefzadeh $\mathrm{H}$ and Sharghi M (2012): Comparative study of topical $80 \%$ trichloroacetic acid with $35 \%$ trichloroacetic acid in the treatment of the common wart. J Drugs Dermatol., 11:66-69.

11. Rezk H and Gaber M (2017): Evaluation of Topical Potassium Hydroxide Solution for Treatment of Plane Warts. Stem Cell., 8(2):71-75.

12. Saini S, Dogra N and Dogra D (2016): A prospective randomized open label comparative study of efficacy and safety of intralesional measles, mumps and rubella vaccine versus $100 \%$ trichloroacetic acid application in the treatment of common warts. Int J Res Med Sci., 4(5): 1529-1533.

13. Yaghoobi $R$, Pazyar $N$ and Maleki $B$ (2019): Comparative Efficacy of 50\% Trichloroacetic Acid Solution with 10\% Potassium Hydroxide Solution in the Treatment of Plane Warts. Journal of Pharmaceutical Research International., 27(4): 1-10. 


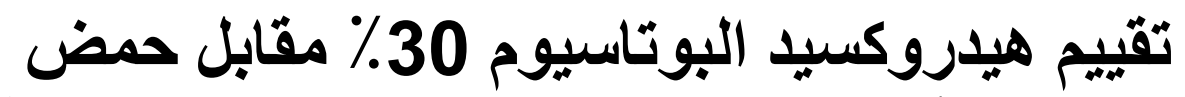

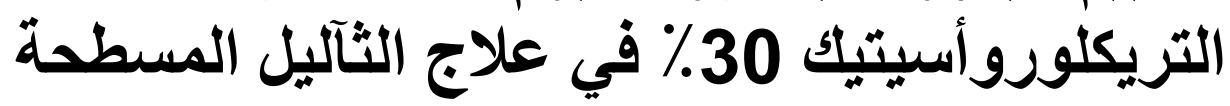

عطية عطية علي عطية العوضي، حامد محمد أحمد عبده، محمد عبدالموجود عامر

قسم الأمر اض الجلدية و التناسلية وأمراض الأكورة، كلية الطب، جامعة الأزهر

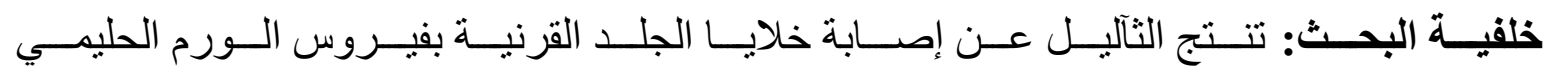

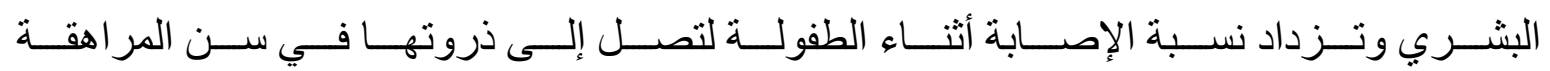

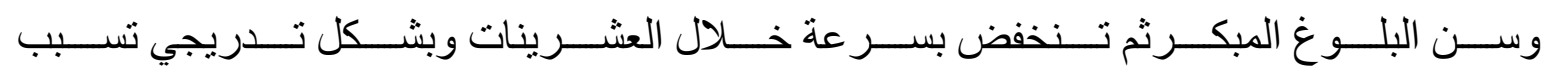

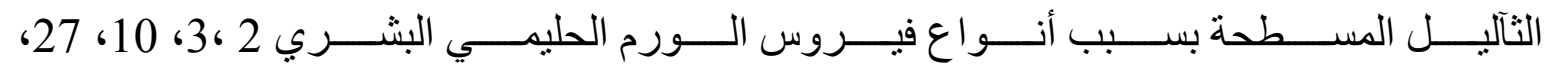

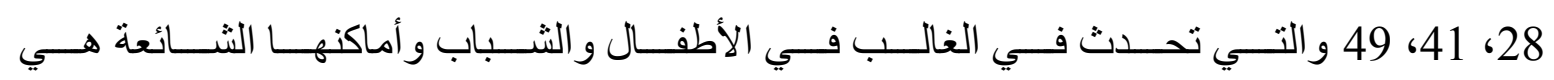
الوجه وظهر اليدين و السيقان.

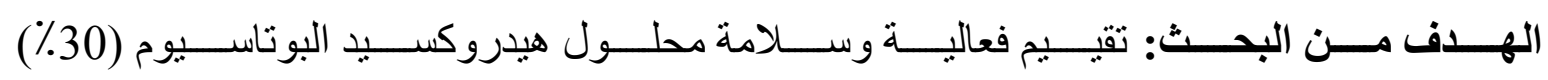
مقابل حض ثلاثي الكلورو اسيتيك المحل (30٪) في علاج الثآليل المسطحة.

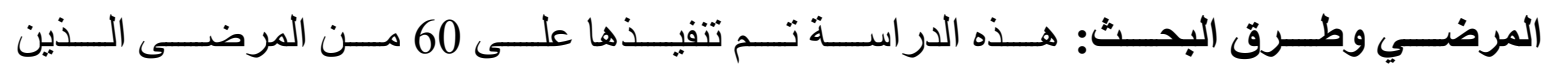

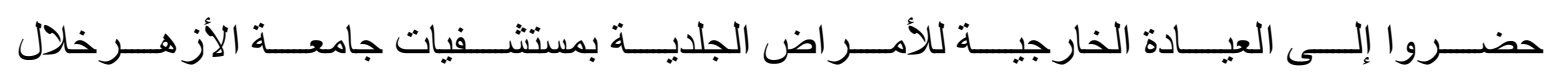



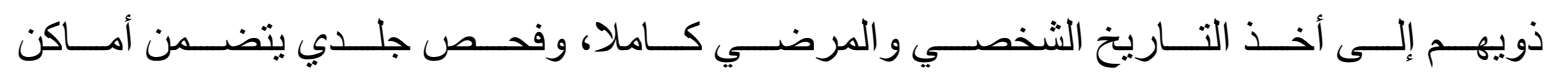
الثآليل المسطحة، و الثقاط الصور قبل وبعد العلاج.

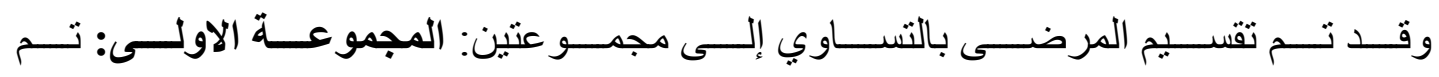

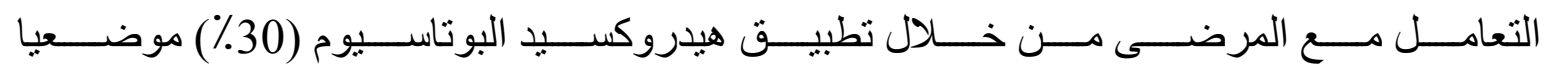



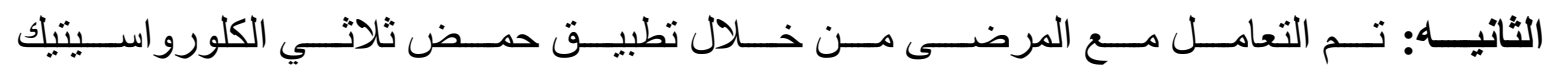

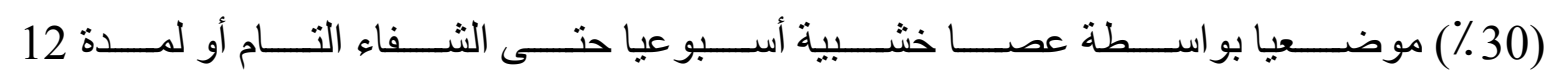
أسبوع.

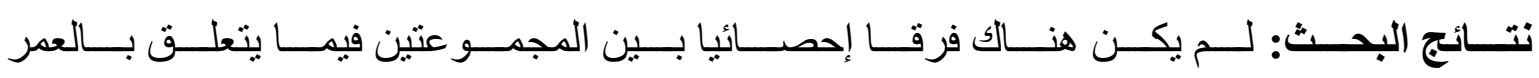



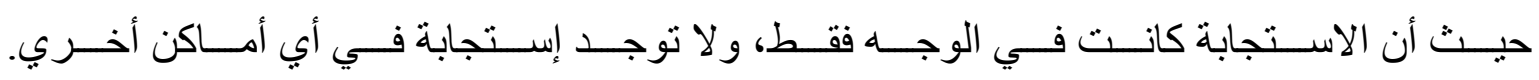


EVALUATION OF TOPICAL 30\% POTASSIUM HYDROXIDE VERSUS... 2063

و بعـــ 12 أســبوعا مــن تطبيــق العـلاج علــى المجموعـة الأولـي تــم التحسـن الكامـل فـي

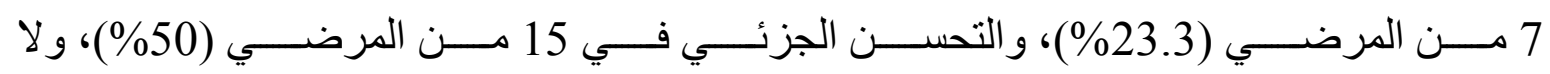

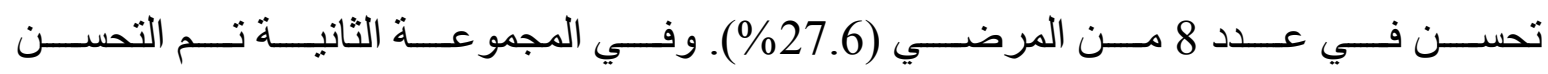


(53.3\%)، ورلا تحسن في 7 من المرضي (23.3\%).

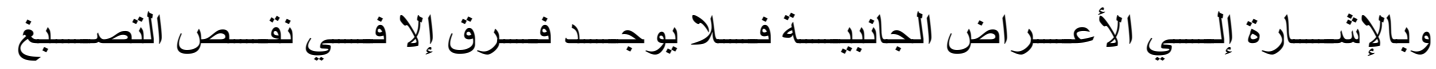

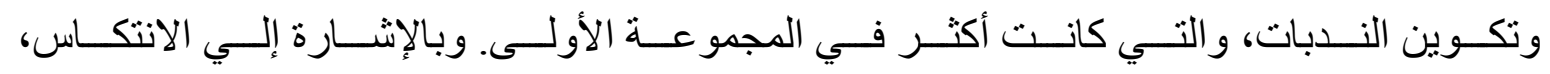

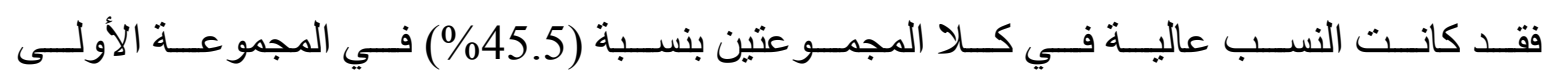
وبنسبة (52.2\%) في المجموعة الثانية.

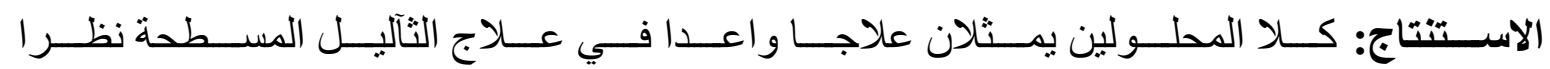



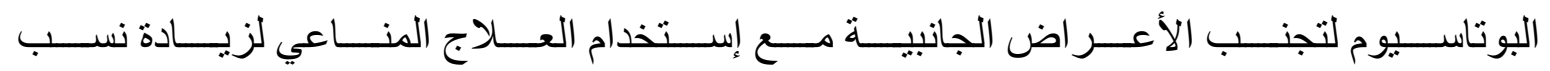
الثفاء و تقليل فرص الانتكاس. 